\title{
PELUANG MEDIA INTERAKTIF DALAM MENUNJANG EFEKTIVITAS PEMBELAJARAN TEMATIK DI SEKOLAH DASAR
}

\author{
Adi Sumarsono ${ }^{1}$, Murni Sianturi ${ }^{2}$ \\ ${ }^{1}$ Jurusan Pendidikan Jasmani Kesehatan dan Rekreasi, Universitas Musamus \\ ${ }^{2}$ Jurusan Pendidikan Matematika, Universitas Musamus \\ email: adi@unmus.ac.id \\ email: murni@unmus.ac.id
}

\begin{abstract}
The purpose of this research was to investigate the effect of interactive media to support the effectiveness of thematic learning in elementary schools. This research was an experimental method with one group pretest posttest design. The sample of this research was second grade students of three schools such as SD YPK Mopah Lama, SD Wasur II and SD Theresia Buti Merauke. The number of students was 42 students. The results of data analysis revealed that there was a significant effect on the improvement of thematic learning by applying interactive media, as evidenced by the value of $t_{\text {count }}>t_{\text {table }}(3.656>1.845)$. Based on the experimental results, there was an increase of 2.476 or $6.11 \%$. Furthermore, based on the effectiveness of the applying of interactive media was in the good category.
\end{abstract}

Keyword: interactive media; thematic learning

Abstrak. Tujuan penelitian ini untuk mengetahui pengaruh media interaktif dalam menunjang efektifitas pembelajaran tematik di Sekolah Dasar. Penelitian ini adalah metode eksperimen dengan one group pretest posttest design. Sampel yang digunakan dalam penelitian ini adalah siswa kelas II yang terdiri dari tiga sekolah yaitu SD YPK Mopah Lama, SD Wasur II dan SD Theresia Buti Kabupaten Merauke. Jumlah sample yaitu 42 siswa. Hasil analisis data menunjukkan terdapat pengaruh yang signifikan terhadap peningkatan pembelajaran tematik setelah diberikan pembelajaran menggunakan media interaktif, terbukti dari nilai $t_{\text {hitung }}>t_{\text {tabel }}$ (3,656>1,845). Berdasarkan hasil eksperimen mengalami peningkatan sebesar 2,476 atau sebesar $6,11 \%$. Selanjutnya berdasar efektifitas penggunaan media interaktif masuk dalam kategori baik.

Kata kunci: media interaktif; pembelajaran tematik

\section{PENDAHULUAN}

Pembelajaran di lingkup Sekolah Dasar mempunyai peran yang penting dalam menanamkan keilmuan sejak usia dini. Hal ini dikarenakan pembelajaran yang dilakukan pada usia dini merupakan dasar dalam mengarungi kehidupan selanjutnya. Proses pembelajaran yang dilakukan selama dalam Pendidikan Dasar mempunyai keunikan tersendiri. Dikatakan unik karena pada saat yang sama dalam pertumbuhan usia sekolah, dilakukan pembelajaran yang sudah mengarah pada pendidikan kognitif, afektif dan psikomotor. Peran inilah yang harus dimaksimalkan oleh seorang guru dalam mencapai tujuan pembelajaran secara bersama-sama.

Proses pembelajaran guru terkadang melakukan pembelajaran yang sama dan melakukan pengulangan materi yang sama pada kelas pada siswa yang berbeda. Hal yang ditemui di lapangan berdasarkan hasil observasi lapangan ditemukan permasalahan yang dihadapi guru Sekolah Dasar khususnya pada tingkat bawah yaitu, Pertama siswa akan merasa tertarik jika dikenalkan pembelajaran melalui obyek yang kongkrit nyata di dalam kehidupan sehari-hari. Kedua, pada kelas pararel guru merasa kesulitan mengulang materi yang sama pada tema yang sudah ditetapkan. 
Ketiga, siswa nampak antusias jika menggunakan perangkat teknologi dalam pembelajaran, hal ini dikarenakan siswa sudah akrab dengan smartphone yang didalamnya terdapat kemudahan dalam mengakses informasi. Keempat, berdasarkan wawancara dengan guru kelas ternyata pada Sekolah Dasar peran penyampaian informasi berupa materi pelajaran sangat memerlukan media. Secara khusus media yang dimaksud adalah media yang melibatkan perangkat komputer yang dapat menampilkan layar, gambar dan suara sekaligus yang dapat mengakomodasi penyampaian materi pembelajaran sesuai tema.

Berdasarkan permasalahan yang ada di Sekolah Dasar diatas maka penelitian ini memberikan solusi akan kebutuhan guru Sekolah Dasar dalam memberikan materi kepada siswa secara efektif dan maksimal. Adapun solusi yang di lakukan melalui penelitian ini yaitu mengembangkan media pembelajaran interaktif.

\section{Media Interaktif}

Tujuan penyampaian pesan dalam setiap proses interaksi adalah tersampaikannya informasi secara detail dan lengkap sehingga penerima informasi dapat menerima serta dapat memahami informasi yang telah diterima. Dalam proses pembelajaran di Sekolah interaksi penyampaian informasi selalu dilakukan dalam proses belajar mengajar. Untuk itu guru dalam proses pembelajaran harus mampu membuat media yang dapat memudahkan proses tranfer ilmu kepada siswa. Kata Media dalam KKBI (2005:756) mengandung arti alat (sarana) untuk menyebarluaskan informasi. Pendapat lain dalam mengartikan arti kata media (Smaldino, Lowther, \& Russall, 2008) medium, a means of comunication. Derived from the latin medium (between) the refers to anything that carries information between a source and a receiver. Yang dapat diartikan bahwa media merupakan sebuah komunikasi yang melibatkan dua pihak yaitu antara sumber informasi dan penerima informasi. Dari pendapat para ahli di atas dapat disimpulkan bahwa media pembelajaran adalah suatu bentuk sarana yang digunakan untuk menyampaikan pesan dalam bentuk menarik, sehingga para audien dapat mengerti dan memahami pesan yang telah disampaikan. Media pembelajaran juga dapat berguna untuk memperlancar interaksi antara guru dengan siswa sehingga kegiatan pembelajaran lebih efektif dan efisien. Bentuk-bentuk media juga sangat beragam, di mana dimaksudkan untuk mempermudah para pengguna dalam mengaplikasikan media disaat situasi berbeda.

Penggunaan media yang tepat tentunya semakin memaksimalkan proses pembelajaran untuk menuju keberhasilan pendidikan. Media sebagai salah satu cara dalam proses penyampaian materi pastinya memiliki banyak manfaat di dalamnya. Menurut (Arsyad, 2011) manfaat praktis dari penggunaan media pembelajaran di dalam proses belajar mengajar adalah 1) Media pembelajaran dapat memperjelas penyajian pesan dan informasi sehingga dapat memperlancar dan meningkatkan proses dan hasil belajar. 2) Media pembelajaran dapat meningkatkan dan mengarahkan perhatian anak sehingga dapat menimbulkan motivasi belajar, interaksi yang lebih langsung antara siswa dan lingkungannya, dan kemungkinan siswa untuk belajar sendiri-sendiri sesuai dengan kemampuan dan minatnya. 3) Media pembelajaran dapat mengatasi keterbatasan indera, ruang dan waktu. Media pembelajaran dapat memberikan kesamaan pengalaman kepada siswa tentang peristiwa-peristiwa di lingkungan sekitar, serta memungkinkan terjadinya interaksi langsung dengan guru, masyarakat, dan lingkungannya. Melalui media yang dikemas dengan menarik dapat membuat para siswa-siswi terpukau, sehingga tingkat konsentrasi terhadap penyampaian materi akan lebih tinggi. Hal tersebut dimaksudkan untuk mencapai hasil yang lebih baik dibandingkan tanpa menggunakan media pembelajaran.

Penyampaian pesan dan informasi melalui media harus mempunyai kualitas. Kualitas menjadi tolak ukur dalam menentukan baik buruknya suatu media pembelajaran. Tampilan yang disusun secara seksama tentunya akan membuat 
pengguna menjadi lebih tertarik dan bersemangat dalam proses kegiatan belajar mengajar. Beberapa kriteria seperti tampilan, warna, tulisan, desain, materi, dan tingkat kesulitan harus dipenuhi agar suatu media dikategorikan baik. Pendapat (Walker \& Hess, 2000) menyatakan bahwa untuk mengetahui kualitas media pembelajaran harus dilihat dari beberapa kriteria 1) Kualitas materi dan tujuan yang meliputi ketepatan, kelengkapan, kepentingan, keseimbangan, daya tarik, kewajaran, dan kesesuaian dengan situasi peserta didik. 2) Kualitas pembelajaran, yang meliputi memberikan kesempatan belajar, memberikan untuk belajar, kualitas memotivasi, fleksibilitas instruksional, hubungan dengan program pembelajaran lainnya, kualitas tes dan penilaiannya dapat memberikan dampak bagi peserta didik, dan dapat memberikan dampak bagi guru serta proses pembelajaran.

Pendapat lain disampaikan oleh (Newby, 2004) menyatakan bahwa untuk mengetahui kualitas media pembelajaran harus mempertimbangkan tiga hal, yaitu; (1) Method, yaitu teknik dan prosedur yang digunakan dalam pembelajaran, (2) Media, yaitu media yang digunakan dalam pembelajaran untuk menarik minat peserta didik, (3) Material, yaitu sisi pembelajran yang meliputi motivasi, orientasi, informasi, aplikasi, dan evaluasi. Sedangkan (Chee \& Wong, 2003) menyatakan bahwa utnuk mengetahui kualitas media pembelajaran juga dapat ditinjau dari empat hal, yaitu; (1) Appropriatness adalah materi yang disampaikan harus disesuaikan dengan karakteristik peserta didik, lingkungan sekolah dan kurikulum yang berlaku, (2) Accuracy, currency and clarity adalah materinya akurat, up to date, jelas dan memaparkan konsep, valid, tidak bias serta sesuai dengan tingkat kesulitan pemahaman peserta didik, (3) Screen presentation and design. Dari pendapat para ahli di atas dapat disimpulkan bahwa kualitas media pembelajaran dapat dikatakan baik apabila kriteria telah terpenuhi. Kriteria tersebut adalah pemilihan materi yang tepat, karakteristik pengguna, tampilan media yang menarik, serta kemudahan dalam menggunakan media pembelajaran. Media pembelajaran juga membuat interaksi langsung antara penguna dengan materi pelajaran.

Manfaat dari pengimplementasian media dalam sebuah kegiatan proses pembelajaran sangat tinggi. Penggunaan Media Interaktif dalam pembelajaran memberikan manfaat yang begitu tinggi terhadap proses pembelajaran seperti meningkatkan pemahaman konsep dan meningkatkan prestasi belajar peserta didik (Mahya \& Suardiman, 2013). Selain bermanfaat, kegunaan dari media interaktif juga dipandang sebagai solusi pembelajaran yang terstruktur. Konsep interaktif dalam pembelajaran memiliki tiga unsur, yaitu urutan-urutan instruksional yang dapat disesuaikan jawaban atau respon siswa, umpan balik yang dapat disesuaikan (Arsyad, 2011). Melalui media interaktif proses pembelajaran yang dilakukan oleh guru dapat berjalan dua fihak guna memberikan informasi dalam pembelajaran. Siswa yang dahulunya hanya mendengar dan duduk diam, melalui media pembelajaran interaktif dapat tampil atraktif komunikasi pembeljaran yang efektif. Sebuah media pembelajaran dapat membantu guru dalam menyampaikan materi kepada siswa. hal ini mengakibatkan siswa lebih mudah dalam menerima infrmasi, guru juga tidak perlu menjelaskan berulang-ulang dalam kelas yang berbeda karena materi telah disajikan dalam sebuah media pembelajaran (Ratnasari, 2016).

\section{METODE PENELITIAN}

Penelitian ini adalah penelitian eksperimen. Desain penelitian ini adalah dalam bentuk one group pretest-posttest design. Pada desain ini tidak terdapat kelompok kontrol, dan subyek tidak ditempatkan secara acak. Kelebihan desain ini adalah dilakukan pretest dan posttest sehingga dapat diketahui dengan pasti perbedaan hasil akibat perlakuan yang diberikan (Maksum, 2008). Sampel dalam penelitian ini adalah siswa kelas II Sekolah Dasar yang berjumlah 42 siswa. Instrumen dalam penelitian ini adalah tes hasil belajar siswa dan untuk mengukur efektifitas dari media pembelajaran menggunakan lembar 
FCE (Formative Class Evaluation). FCE digunakan untuk mengetahui seberapa efektif pembelajaran dikelas dari sisi pendapat siswa (Wijaya, Agus, \& Astono, 2006). Lembar kuisioner FCE diberikan dan diisi oleh siswa setelah proses pembelajaran berlangsung. Tahapan yang dilakukan dalam penelitian meliputi tahapan perencanaan, pelaksanaan dan tahapan analisis data. Pada tahap perencanaan hal yang disiapkan adalah materi media interaktif yang sesuai dengan materi pada tema kelas II, persiapan instrumen yang akan digunakan dalam pretest dan posttets selanjutnya penentuan sekolah serta penentuan siswa pada materi yang sama. Pada tahap pelaksanaan dilakukan pertama kali adalah melakukan pretest, selanjutnya dilakukan perlakuan kepada siswa pada pemberian materi pembelajaran dengan media interaktif sesuai dengan tema yang diajarkan oleh guru selama tiga kali pertemuan, selanjutnya dilakukan postttest. Selanjutnya pada tahap analisis data hal yang dilakukan adalah statistik deskriptif, data yang diperoleh dari hasil pengamatan aktivitas siswa dalam mengikuti pembelajaran, selanjutnya dilakukan analisis data menggunakan statistik inferensial yang digunakan menguji hipotesis parametrik yang sebelumnya sudah dilakukan uji prasarat statistik. Jenis uji ststistik yang digunakan dalam uji hipotesis adalah paired sample t-test. Kriteria pengambilan keputusan adalah $\mathrm{H}_{0}$ diterima jika taraf signifikansi $\mathrm{p} p \geq 0,05=\alpha$, tetapi tolak $\mathrm{H}_{0}$ jika taraf signifikansi $p$ memiliki hargaharga lain.

Instrumen penelitian menurut Arikunto (2003: 135) adalah alat bantu yang dipilih dan digunakan oleh peneliti dalam kegiatanya mengumpulkan data agar kegiatan tersebut menjadi sistematis dan dipermudah memperolehnya.Instrumen yang digunakan dalam penelitian ini meliputi :

\section{Tes Hasil Belajar}

Tes hasil belajar merupakan tes uraian yang digunakan untuk mengukur tingkat penguasaan siswa terhadap materi.

Kuisioner FCE (Formative Class Evaluation) yang dilakukan terhadap siswa sebagai pelaku pembelajaran dengan menggunakan media interaktif. Penggunaan instrumen FCE menurut (Wijaya,2006) penggunaan lembar kuisioner digunakan untuk mengetahui seberapa efektif pembelajaran yang dilakukan oleh guru menurut sisi pendapat siswa. Adapun isi dari instrumen FCE terdiri dari empat komponen pokok yaiitu hasil, kemauan, metode dan kerjasmana. Validitas instrumen FCE (Formative Class Evaluation) adalah 0,78 dengan derajat vaiditas Tinggi. Kategori skor dari lembar FCE (Formative Class Evaluation) dapat dilihat pada tabel berikut:

Tabel 1. Kategori Skor Lembar FCE

\begin{tabular}{lll}
\hline Skor & Nilai & Kategori \\
\hline $2,77-$ keatas & 5 & Sangat baik \\
$2,58-2,76$ & 4 & Baik \\
$2,34-2,57$ & 3 & Sedang \\
$2,15-2,33$ & 2 & Kurang \\
$2,14-$ ke bawah & 1 & Kurang Sekali \\
\hline
\end{tabular}

Untuk mempermudah dalam penilaian jawaban dari masing-masing jawaban item pertanyaan diberikan alternatif skor jawaban, yaitu jawaban ya nilai 3 , tidak tahu dengan nilai 2 dan tidak dengan nilai 1. Masing-masing hasil pengisian kuisioner FCE dipisahkan dengan siswa laki-laki dan siswa perempuan.

\section{HASIL DAN PEMBAHASAN}

Penelitian ini bertujuan untuk mengetahui perbedaan peluang pengaruh media interaktif dalam menunjang efektifitas pembelajaran tematik di Sekolah Dasar. Data yang didapatkan dari penelitian ini berupa nilai pretest dan nilai posttest, serta nilai dari lembar FCE. Berdasrkan 
hasil penelitian yang sudah dilakukan dapat

dijabarkan data sebagai berikut:

Tabel 2. Data Pretest dan Psotest

\begin{tabular}{lcc}
\hline \multicolumn{1}{c}{ Data } & Pretest & Posttest \\
\hline Sampel & 42 & 42 \\
N. Ideal & 100 & 100 \\
N. Tertinggi & 100 & 100 \\
N. Terendah & 4 & 40 \\
N. Rata-rata & 60,45 & 80,04 \\
N. Varians & 573,432 & 225,532 \\
\hline
\end{tabular}

Berdasarkan data pada tabel diatas dapat diketahui terjadi peningkatan nilai dari prestest dan postest. Dari masing masing sampel yang dilakukan dalam penelitian yang berjumlah 42 siswa, terjadi peningkatan rata-rata dari asalnya 60,45 menjadi 80,04. Selanjutnya untuk meyakinkan selisih rata-rata dari data pretest dan data posttets dapat dilihat dari nilai gain dari masing-masing data yang dijabarkan sebagai berikut:

Tabel 3. Rekapitulasi Nilai N-Gain

\begin{tabular}{cllll}
\hline Data & Pretest & Postest & S. maks & $\boldsymbol{N}$-gain \\
\hline Rata-rata & 60,45 & 80,04 & 100 & 0,464 \\
\hline
\end{tabular}

Berdasarkan hasil perhitungan ratarata nilai $n$-gain, dapat disimpulkan terdapat peningkatan nilai posttest yang berada pada kategori sedang. Selanjutnya berdasar data yang sudah didapatkan dari perhitungan nilai pretest dan posttes diatas, dilakukan uji statistik guna mengetahui hipotesis yang menjadi dugaan sementara dari penelitian ini. Sebelum dilakukan uji statistik keseluruhan data dilakukan uji prasarat terlebih dahulu. Adapun pemaparan dari uji prasarat dapat dijelaskan sebagai berikut:

Uji Normalitas

Pemaparan data dari teknik uji normalitas dalam penelitian ini menggunakan Chi Kuadrat yang dapat dilihat pada tabel berikut ini:

Tabel 4. Uji Normalitas

\begin{tabular}{cll} 
& \multicolumn{2}{l}{ Tabel 4. Uji Normalitas } \\
\hline Statistik & \multicolumn{1}{c}{ Presttest } \\
\hline $\mathrm{N}$ & 42 & 42 \\
$\mathrm{~A}$ & 0,05 & 0,05 \\
$\chi_{\text {hitung }}^{2}$ & 8,41 & 9,52 \\
$\chi_{\text {tabel }}^{2}$ & 2,25 & 2,25 \\
Kesimpulan & Normal & Normal \\
\hline
\end{tabular}

Berdasarkan pemaparan data pada tabel diatas dapat dilihat bahwa data pretest dan dan data posttest keduanya berdistribusi normal.
Uji Homogenitas

Pemaparan data dari teknik uji homogenitas dalam penelitian ini menggunakan $U j i F$ yang dapat dilihat pada tabel berikut ini:

Tabel 5. Uji Homogenitas

\begin{tabular}{ccc}
\hline Statistik & Pretest & Postest \\
\hline$S^{2}$ & 873,653 & 476,534 \\
$\mathrm{~F}_{\text {hitung }}$ & 1,53 & 1,11 \\
$\mathrm{~F}_{\text {tabel }}$ & 1,89 & 1,89 \\
Kesimpulan & Homogen & Homogen \\
\hline
\end{tabular}


Berdasarkan tabel diatas dapat diketahui bahwa data pretest dan data posttest dalam populasi yang homogen. Setelah diketahui bahwa data yang diperoleh dari hasil penelitian ini berdistribusi normal dan homogen maka dilanjutkan pada uji statistik:

\section{Uji Hipotesis}

Uji hipotesis yang dilakukan dalam penelaitian ini adalah menggunakan paired sample test yang digunakan untuk menjawab rumusan masalah penelitian ini yaitu mengetahui peluang dari perbedaan efektifitas pembelajaran tematik di Sekolah Dasar sebelum dan sesudah diajarkan menggunakan media interaktif. Adapun kriteria pengujiannya dalam penelitian ini yaitu diterima $\mathrm{H}_{\mathrm{o}}$ jika $t_{\text {hitung }}<t_{\text {tabel }}$ yang berarti dalam kondisi lain $\mathrm{H}_{\mathrm{o}}$ ditolak. Hasil perhitungan paired sample t-test pada penelitian ini dapat dilihat pada tebel berikut:

Tabel 6. Hasil Uji Paired Sample t-test

\begin{tabular}{ll}
\hline \multicolumn{1}{r}{ Statistik } & \multicolumn{1}{c}{ Data Pretest - Posttest } \\
\hline $\mathrm{N}$ & 42 \\
$\sum d$ & 854 \\
$M d$ & 22.76 \\
$t_{\text {hitung }}$ & 3,656 \\
$t_{\text {tabel }}$ & 1,845 \\
Kesimpulan & Ho ditolak dan $\mathrm{H}_{1}$ diterima \\
\hline
\end{tabular}

Berdasarkan hasil perhitungan uji hipotesis yang sesuai dalam penelitian ini diperoleh $\mathrm{t}$ hitung $=3,65$ dengan $\mathrm{df}=42$ dan taraf signifikan yaitu $5 \%$ dan yang diperoleh $\mathrm{t}$ tabel $=1,845$. Berdasarkan pemaparan data diatas dapat disimpulkan bahwa, $H_{o}$ ditolak dan $H_{l}$ diterima. Dari keimpulan ini dapat di simpulkan bahwa terdapat perbedaan efektifitas hasil belajar siswa sebelum dan sesudah diajar dengan menggunakan media interaktif. Hipotesis ini mengindikasikan bahwa media Interaktif mempunyai peran yang sentral dalam proses pembelajaran. Interaksi yang diciptakan oleh guru dapat memberi pemahaman yang baru kepada siswa. Media interaktif membuat siswa menjadi semakin bersemangat, karena interaksi dilakukan guru melalui media mampu menyatukan pemahaman dan pemikiran siswa tentang materi yang sedang dibahas.

Data Formative Class Evaluation (FCE) Berdasarkan hasil penelitian didapatkan data yang dipaparkan pada tabel berikut:

Tabel 7. Hasil lembar FCE siswa Putra

\begin{tabular}{llcc}
\hline No & Subyek & Average & Ket \\
\hline 1 & Kelas II SD YPK Mopah Lama & 4 & Baik \\
2 & Kelas II SD Wasur 2 & 4 & Baik \\
3 & Kelas II Theresia Buti & 4 & Baik \\
\hline
\end{tabular}

Berdasar pemaparan tabel diatas dapat dijelaskan bahwa dari Siswa kelas II dari Tiga Sekolah yang berbeda, hasil pengisian FCE dari Siswa laki-laki mengutarakan pendapatnya bahwa implementasi pembelajaran tematik dengan menggunakan media interaktif masuk dalam kategori baik. Dari hasil observasi yang dilakukan pada proses pembelajaran selama tiga pertemuan di dapatkan data tentang tiga aspek yang di observasi yaitu aspek sikap, aspek kognitif dan aspek psikomotor dapat dilihat pada diagaram berikut ini: 


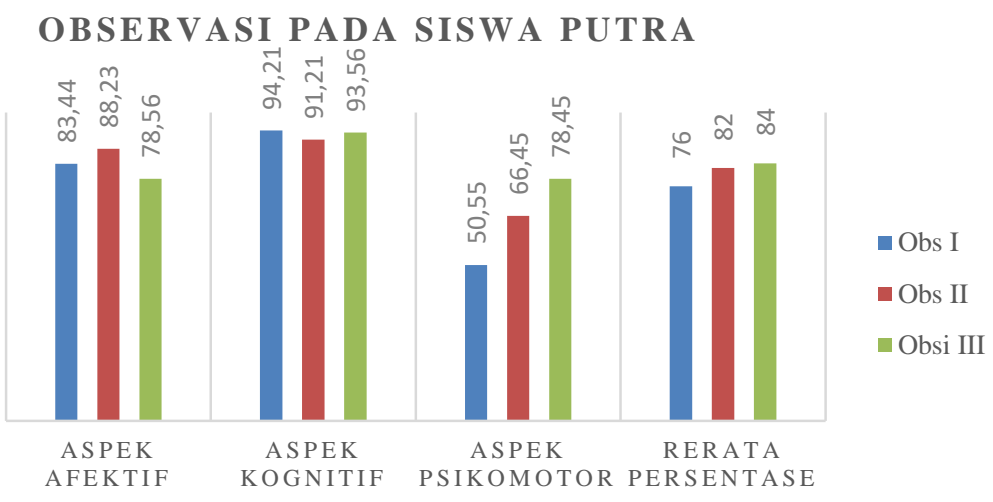

Gambar 1. Hasil Observasi Siswa Putra

Berdasarkan dari hasil observasi yang dilakukan oleh tiga orang observator dalam penelitian, yang dilakukan sebelum selama dan sesudah pemebelajaran pada siswa putra dapat iketahui bahwa menggunakan media pembelajaran interaktif secara rata-rata masuk dalam kategori baik. Ketiga ranah dalam pembelajaran aktif dalam melakukan pengamatan, penjelasn dan menyimpan memori sesuai dengan materi yang diajarkan guru.

Sedangkan hasil pengisian dari siswi perempuan dapat dilihat pada tabel berikut:

Tabel 8. Hasil Lembar FCE Siswi Putri

\begin{tabular}{llcc}
\hline No & \multicolumn{1}{c}{ Subyek } & Average & Ket \\
\hline 1 & Kelas II SD YPK Mopah Lama & 4 & Baik \\
2 & Kelas II SD Wasur 2 & 4 & Baik \\
3 & Kelas II Theresia Buti & 4 & Baik \\
\hline
\end{tabular}

Berdasar pemaparan tabel diatas dapat dijelaskan bahwa dari Siswa kelas II dari Tiga Sekolah yang berbeda, hasil pengisian FCE dari Siswa perempuan mengutarakan pendapatnya bahwa implementasi pembelajaran tematik dengan menggunakan media interaktif masuk dalam kategori baik. Sedangkan hasil observasi yang juga dilakukan oelh tiga orang observator pada pengamatan ranah afektif, kognitif dan ranah psikomotor dapat dijelaskan pada diagram berikut ini:

\section{OBSERVASI PADA SISWI PUTRI}

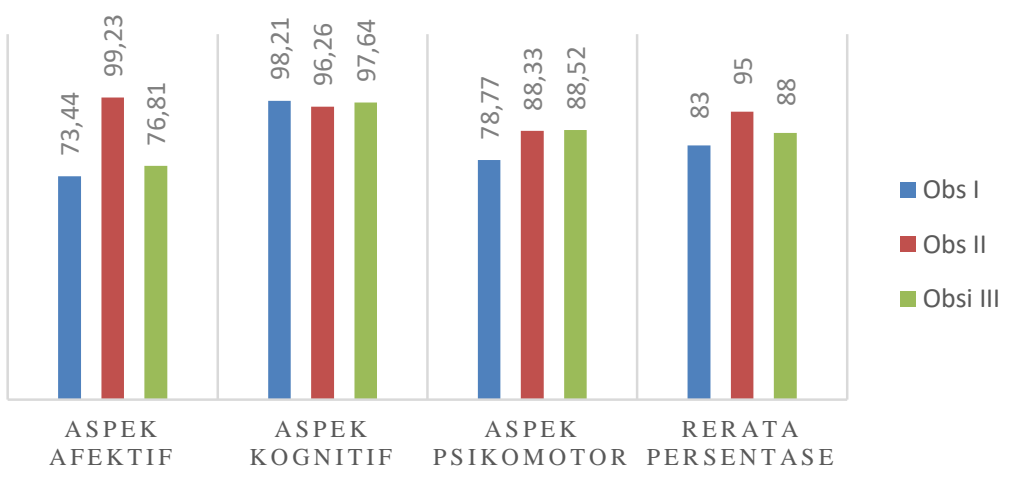

Gambar 2. Hasil Observasi Siswa Putri 
Berdasarkan dari hasil observasi yang dilakukan oleh tiga orang observator dalam penelitian, yang dilakukan sebelum selama dan sesudah pemebelajaran pada siswi putri dapat diketahui bahwa menggunakan media pembelajaran interaktif secara rata-rata masuk dalam kategori baik. Ketiga ranah dalam pembelajaran aktif dalam melakukan pengamatan, penjelasan dan menyimpan memori sesuai dengan materi yang diajarkan guru. Aplikasi Interaktif menarik siswa, dari semula belum tau menjadi tau dengan tambahan materi yang diberikan menggunakan media yang dapat membuat rasa interaksi antara sesama murid, interaksi dengan guru serta interaksi dengan materi yang disapiakan guru.

\section{Pembahasan}

Berdasarkan hasil penelitian yang telah dipaparkan, media interaktif memberikan dampak positif dalam menunjang efektivitas pembelajaaran di sekolah Dasar. Hidayati (2017) mengungkapkan bahwa pembelajaran menggunakan multimedia interaktif sangat efektif dalam meningkatkan hasil belajar matematika siswa. Kecenderungan hasil belajar matematika siswa dengan pembelajaran tersebut termasuk kategori sangat tinggi. Rizal, Rahmat \& Rizal (2016) juga menyatakan bahwa pembelajaran interaktif dapat meminimalisir kendalakendala yang selama ini terjadi saat pemeblajaran di kelas. Hal ini dikarenakan bahwa dalam pembelajaran dengan menggunakan media interaktif, siswa terlibat dan dapat mengaktifkan segala kemampuan mereka. Dengan pembelajaran media interaktif, ke tiga gaya belajar yaitu audio, visual dan kinestetik difungsikan sehingga setiap anak dengan gaya belajar masing-masing dapat terlibat dalam pembelajaran.

Tentu dalam menyusun suatu media interaktif, perlu diperhatikan konten yang ada di dalamnya. Konten yang ada harus serelavan mungkin dengan kebutuhan siswa dan tujuan pembelajaran. Agar konten yang disajikan relevan dengan siswa, materimateri yang konstekstual akan menolong siswa mudah untuk memahami materi. Selain itu, dengan materi yang kontekstual juga, siswa tidak sungkan untuk menyatakan pendapatnya karena apa yang dipelajari adalah hal-hal yang mereka bisa saksikan dalam kehidupan mereka seharihari (Nurlaela, Wahyudin, \& Hamdani, 2016). Dalam penelitian ini, siswa terlibat aktif dalam pembelajaran, juga didukung oleh kemampuan guru dalam menyampaikan konten yang ada dalam media interaktif.

Penyampaian yang tepat dengan interaksi yang tepat memungkinkan siswa yang awalnya tidak antusias, akhirnya tertarik untuk terlibat dalam pembelajaran.

Pembelajaran dengan menggunakan media interaktif memberi manfaat bagi pembelajaran tematik yang sekarang ini digalakkan dalam kurikulum 2013. Hal ini terlihat dari penelitian terdahulu yang telah membuktikan bahwa pembelajaran media interaktif dapat diterapkan dalam mata pelajaran IPA, agama bahkan matematika (Nurlaela, Wahyudin, \& Hamdani, 2016; Rizal, Rahmat, \& Rizal, 2016; Hidayati \& Kusmanto, 2017).

\section{SIMPULAN}

Hasil wawancara dari guru ditemui fakta bahwa melalui media Interaktif guru mampu memberikan jenis pembelajaran yang intinya sama akan tetapi dengan pengalaman yang berbeda. Masih menurut guru dengan menggunakan media interaktif siswa dalam kelas dapat mengikuti pembelajaran dengan tertib, hal ini akan mempengaruhi iklim kelas yang positif dan yang jelas akan berpengaruh terhadap hasil belajar siswa. Selain itu guru juga menjadi mampu mengelola kelas dengan baik, sehingga tercipta suasana yang kondusif dan siswa dapat melakukan belajar dikelas. Media interaktif dapat digunakan dalam penyampaian materi sangat mempengaruhi kemampuan baik sikap maupun cara berfikir siswa. 


\section{DAFTAR RUJUKAN}

Arsyad, \& Azhar. (2011). Media Pembelajaran. Jakarta: Raja Grafindo Persada.

Hidayati, N., \& Kusmanto, B. (2017). Efektivitas pembelajaran menggunakan multimedia interaktif (adobe flash CS6) terhadap hasil belajar matematika siswa kelas V SD N Jurug Sewon. Trihayu: Jurnal Pendidikan Ke-SD-an, 3(3), 169-172.

Mahya, A. F., \& Suardiman, S. P. (2013). Pengembangan Multimedia Interaktif untuk Mata Pelajaran Ilmu Pengetahuan Sosial (IPS) Sekolah Dasar Kelas V. Jurnal Prima Edukasia, 5.

Maksum, A. (2008). Metodologi Penelitian dalam Olahraga. Surabaya: FIK Unesa Press.

Mardapi, D. (2008). Teknik penyusunan instrumen tes dan non tes. Yogyakarta: Mitra Cendekia Press.

Newby, T. J. (2004). Instructional technology for teaching and learning. New Jersey: Prentice Hall Inc.

Nurlaela, Wahyudin, \& Hamdani, N. A. (2016). Efektivitas penggunaan multimedia pembelajaran interaktif melalui pendekatan CTL dalam meningkatkan hasil belajar siswa tentang pesawat sederhana pada pembelajaran IPA di kelas V sekolah dasar negeri Hanjuan I. JTEP-Jurnal Teknologi Pendidikan dan Pembelajaran, 1(1), 48-59.

Ratnasari, A. (2016). pengembangan media pembelajaran interaktif keselamatan dan kesehatan Kerja (P3K) Pada program studi ketenaga listrikan di sekolah Menengah Kejuruan. Jurnal program studi pendidikan teknik mekatronika Vol. 6, No. 1, 85.

Rizal, A. S., Rahmat, M., \& Rizal, A. S. (2016). Efektivitas multimedia interaktif flash terhadapa pembelajaran pendidikan agama isalam di sekolah menengah pertama. Jurnal Pendidikan Agama IslamTa'lim, 14(2), 169-183.

Smaldino, S. E., Lowther, D. L., \& Russall, J. D. (2008). Instructional technology and media for learning. New Jersey: Pearson.

Walker, D. F., \& Hess, R. D. (2000). Instructional Software. Belmot: Wadworth Publishing Company.

Wijaya, Agus, M., \& Astono. (2006). Uji coba instrumen baku evaluasi pembelajaran dikdasor di SLTP negeri se Kota Sudaranaya. Laporan Khhir Asdep olahraga pendidikan, Kemenegpora, Kemenegpora RI. 
110 JURNAL PENDIDIKAN EDUTAMA, Vol.6, No.2 Juli 2019 